\title{
The Food Security Challenge for the Buffalo Meat Industry: Perspectives from Lao PDR
}

\author{
Sonevilay Nampanya ${ }^{1^{*}}$, James Young ${ }^{1}$, Syseng Khounsy ${ }^{2}$, Russell Bush ${ }^{1}$ and \\ Peter Windsor ${ }^{1}$
}

\author{
${ }^{1}$ Faculty of Veterinary Science, University of Sydney, Camden, NSW 2570, Australia \\ ${ }^{2}$ Department of Livestock and Fisheries, Regional Office, Luang Prabang, Lao PDR
}

\begin{abstract}
The Asiatic swamp buffalo (Bubalus bubalis) is an important livestock species in the Lao People's Democratic Republic (Laos), with smallholder farmers owning the majority of an estimated 774,200 buffalo. Of the estimated 226,400 farm households with buffalo, $78 \%$ have a herd size of four or fewer, kept as a storage of wealth, sale for beef, for manure as fertilizer, and decreasingly, draught power. The total meat consumption in Laos and China was approximately $21 \mathrm{~kg}$ and $58 \mathrm{~kg}$ per capita in 2009 , with an annual growth rate forecast of $4.5 \%$ and $3.1 \%$. Increasing demand for meat in both domestic and neighboring markets offers opportunities for smallholders to gain more income from their livestock, particularly buffalo. However improving buffalo production requires numerous management constraints to be addressed, including: health issues (parasites and endemic diseases, particularly Toxocara vitulorum and Haemorrhagic Septicaemia control), biosecurity and transboundary disease (Foot and Mouth Disease control), nutritional deficits, low reproductive performance, high slaughter rates of pregnant cows, undeveloped trade and marketing systems, limited veterinary and extension service capacity, and potentially climate change and policy impacts. This paper reviews available information on these constraints to identify remaining gaps in knowledge and offer potentially suitable strategic interventions aimed at increasing the supply of buffalo in Laos. With the current rapid rate of economic development expected to continue in Laos and the Greater Mekong Subregion, expansion of the domestic and regional markets for food requires a more biosecure and sustainable supply of safe meat. Improving livestock health, productivity, processing and marketing, particularly of buffalo, is critical to ensuring poor smallholder communities can participate in and access these growing markets, providing improved rural livelihoods, poverty reduction and increased food security.
\end{abstract}

Keywords: Asiatic swamp buffalo (Bubalus bubalis), large ruminant health and production, Laos.

\section{INTRODUCTION}

Lao People's Democratic Republic (Lao PDR or Laos, henceforth) is a land-locked country centrally located in the Greater Mekong Subregion (GMS), sharing borders with five countries; China to the North, Myanmar to the North-West, Thailand to the West, Vietnam to the East and Cambodia to the South. Laos comprises multiple ethnic groups and in 2011 had an estimated population of 6.3 million people [1]. A large majority of the population is dependent on agriculture and the use of natural resources for their livelihoods [2], being engaged in livestock, fishery and forestry activities that contributes approximately $33 \%$ of the total national Gross Domestic Product (GDP) and employs approximately $75 \%$ of the workforce in 2010 [3]. Enhancing food security, improving nutrition and reducing poverty remain complex challenges in Laos [4] where $27 \%$ of the population in 2012 was undernourished [3,5] and approximately $77 \%$ of the total population lives on or below USD2 per day [1].

Although rice production dominates the agricultural sector and accounts for $40 \%$ of land under cultivation

*Address correspondence to this author at the Faculty of Veterinary Science, University of Sydney, Camden, NSW 2570, Australia;

Tel: +61 29351 1785; Fax: +61 29351 1693;

E-mail: snam7362@uni.sydney.edu.au, sonevilay@yahoo.co.uk
[5], large ruminant livestock production in smallholder farming systems is increasingly important, providing animals and meat for sale or consumption, a storage of wealth, fertiliser for crops, draught power for transport and cultivation, and participation in cultural festivities (e.g. bull fighting). Livestock rearing including buffalo provides up to $50 \%$ of smallholder household annual cash income [6-8]. However there are multiple constraints to more modern and optimal production techniques and productivity, including limited availability of land, underfeeding practices with poor quality fodder, major transboundary and endemic disease issues, poor husbandry knowledge, minimal agricultural extension capacity with a lack of knowledge transfer, a low capacity animal health reporting and response system with suboptimal disease surveillance and few outbreak investigations, minimal confirmation of disease diagnoses, plus poor disease prevention and control management [4]. Isolation and absence of year-round road access or alternative transport systems is a further constraint for many smallholder farmers, particularly during the wet season. These constraints and subsistence production attitudes and practices, decrease the ability of many Lao farmers to achieve optimal production and increases their vulnerability to both disease and climate shocks affecting their crops and livestock [9-10]. 
The demand for red meat is rapidly increasing in China and Southeast Asia and is projected to grow by $2.9 \%$ per annum by 2020 [11], driven by the fast growing economies and urbanization in more developed countries of the region, such as China and Vietnam. Despite increasing demand and trading opportunities, many Lao large ruminant farmers have yet to take advantage of these changing circumstances, remaining in a transition between livestock keepers and more market-oriented producers. Improvement in large ruminant livestock production and buffalo productivity in particular, requires that Lao smallholder farmers overcome the numerous production and management constraints including: health issues (parasites and endemic diseases, particularly Toxocara vitulorum and Haemorrhagic Septicaemia control); biosecurity and transboundary disease control (particularly Foot and Mouth Disease); nutritional deficits; supply issues including low reproductive performance and high slaughter rates of pregnant cows; undeveloped trade and marketing systems; limited veterinary and extension service capacity; and potentially the impacts of increasing climatic variability and uncertain policy settings $[4,7,12]$

As Laos and the wider GMS continue the current rapid rate of economic development, the expanding domestic and regional markets for food require a more biosecure and sustainable supply of safe meat and protein. Improving livestock health and productivity is critical to ensure poor people in rural communities can participate in and access these growing markets, with likely benefits to rural smallholder livelihoods including poverty reduction and improved food security. This paper reviews available information on these constraints to identify remaining gaps in knowledge and practices that limit the supply of buffalo to the increasing regional demand, plus offer potentially suitable strategic interventions for improvement to assist in achieving a more sustainable food supply.

\section{POPULATION DYNAMICS, CURRENT CONS- TRAINTS AND FUTURE PROSPECTS}

Lao smallholder farmers typically manage their buffalo with cattle under a mixed crop-livestock system according to the rice cultivation calendar $[8,9,13]$. Based on levels of input and grazing management, three main systems have been described including: (1) all year-round free-grazing; (2) seasonal free-grazing; and (3) a seasonal daytime free-grazing and opportunistic fattening system. In addition, variations in buffalo management reflect variations in crop-livestock management skills, availability of land resources and seasonal feed, plus importantly, farmer knowledge and attitudes towards of large ruminant health and production practices $[9,13]$.

In 2010/11 the Department of Planning of the Ministry of Agriculture and Forestry conducted a national Agricultural Census including all private households with livestock. Agricultural activities of institutional units such as government farms, private companies and schools were excluded. This review paper draws on data from the Lao Agriculture Census [14]. The number of farming households with buffalo declined between 1999 and 2011 (Table 1). Of the 782,800 total farm households, 226,400 (29\%) kept buffalo, contracting by 30\% between 1999 and 2011 [14]. Similarly, the total buffalo population decreased by $22 \%(2.0 \%$ per annum) to 774,200 between 1999 and 2011. Over three-quarters of farm households with

Table 1: Total Farm Households, Households with Buffalo, Buffalo Herd and their Population Change (\%) between 1999 and 2011 by Regions

\begin{tabular}{|c|c|c|c|c|c|}
\hline \multirow{2}{*}{ Region } & \multicolumn{2}{|c|}{ Farm households ('000) } & \multicolumn{2}{c|}{ Buffalo herd } \\
\cline { 2 - 6 } & Total & with buffalo & Population ('000) & \% Change & Growth per annum (\%) $^{*}$ \\
\hline \hline North & 288.9 & 66.4 & 211.8 & -28.6 & -2.8 \\
\hline Central & 336.4 & 95.6 & 355.7 & -18.7 & -1.7 \\
\hline South & 157.5 & 64.4 & 206.7 & -13.3 & -1.2 \\
\hline Total & 782.8 & 226.4 & 774.2 & -21.9 & -2.0 \\
\hline
\end{tabular}

Source: Steering Committee for Lao Census of Agriculture, 2012, Lao Agriculture Census.

*Based on compound growth rates. 
buffalo had four or fewer buffalo, with an average of 3.4 per household. Both the national herd and the number of households with buffalo has decreased dramatically in the past 10 years, raising concerns that Laos will be unable to meet the rising demand for beef.

Significant reductions in both farm households with buffalo and the national buffalo population may be attributable to several factors. Firstly, with more than $61 \%$ of all farm households reporting their use of a twowheeled tractor for ploughing [14], increasing farm mechanisation has largely replaced buffalo kept for draught, enabling the ready sale of buffalo and contributing to reduced numbers [7-8]. Increased mechanisation for draught has been more prominent in provinces along the Mekong river, although some farmers in the more remote provinces (e.g. Huaphanh and Xiengkhoung) still use buffalo for draught in combination with hand tractors. They also continue to value buffalo as a means of wealth accumulation and source of manure for rice cultivation, particularly as the non-alluvial soils in these provinces are less fertile and less suitable for rice production $[7,12]$.

Secondly, there has been a reduction in 'common' grasslands available for grazing due to the expansion of cash crop plantations (e.g. rubber, maize, banana, sugar cane, cassava), particularly in the northern and more recently in the central regions of Laos [14,15]. Reduced grazing land and feed deficiency in the dry season is likely to have led to many smallholder buffalo farmers choosing to sell some of their livestock, rather than be fined when their animals trespass into cash crop plantations of other farmers. Further studies to provide a better understanding of the correlation between the expansion of cash crops and the reduction in buffalo numbers is recommended.

Thirdly, low reproductive performance could also have contributed to reduced buffalo populations. A recent study in northern Laos revealed low calving rates and prolonged inter-calving intervals of fertile buffalo of $41-52 \%$ and $19-21$ months, respectively [9]. Oestrus behavior in buffaloes is considered to be lower intensity than in cattle and is more difficult to detect, plus the distinct seasonal changes in the display of oestrus influences conception and calving rates presumably due to nutritional and lactational anoestrous; female buffalo calving during an unfavorable season may not resume ovarian activity until a more favorable season [16]. Further, poor husbandry practices and absence of reproductive management contributes to low reproductive performance in buffalo in Laos. The standard reproductive management practices of sex segregation, castration of male calves not required for breeding, selective breeding of superior animals and other aspects of breeding management are not practiced widely by smallholder farmers [7-8]. This means there are numerous lost opportunities for improving buffalo reproduction, including delayed age of first calving, prolonged inter-calving intervals, and seasonal anoestrus, as has been reported from other countries [17-19]. An intervention of particular interest is the potential for the early weaning of buffalo beef calves (e.g. at 70-180 days of age). This practice is used where breeding females are at risk of reproductive compromise due to inadequate nutrition [20-21] as the metabolisable energy (ME) requirements of the dam in early lactation are approximately double those of a dry cow and where energy is limited, the cow will lose body condition and weight rapidly [20]. In addition to managing the reproductive cycle so that buffalo cows calve into the wet season and provision of a higher plane of nutrition from forages grown for lactation, strategic early weaning may offer an opportunity for improving buffalo reproductive efficiency in smallholder systems.

Of potential importance to breeding management, is that although slaughtering of pregnant animals for meat is prohibited in Laos [22], a large slaughterhouse survey in five northern provinces of Laos identified that $44 \%$ and $47 \%$ of the female cattle and buffalo slaughtered respectively, were pregnant with gestation lengths ranging from first to last trimesters [23]. Slaughtering of pregnant animals results in calf wastage and undermines reproductive capacity. Although this practice may indicate that smallholder farmers were not aware of their livestock reproductive status at the point of sale, it is widely known that soup made from buffalo uterus and fetus is a delicacy in the Lao cuisine.

It is considered likely that in addition to increasing demand for fattened buffalo from expanding regional markets, a combination of poor husbandry practices may also be contributing to the pressures on the supply of Lao buffalo, explaining the declining population. Encouraging compliance with Veterinary Law including development of enforcement capacity, plus improvement of farmer knowledge, attitudes and practices in breeding and general husbandry management is considered very important in addressing the declining buffalo population in Laos. 


\section{IMPORTANT ENDEMIC DISEASES OF BUFFALO IN LAOS}

Along with feed deficiency in the dry season, the high prevalence of endemic diseases such as Foot and Mouth Disease (FMD), Haemorrhagic Septicaemia (HS), and internal parasites including Toxocara vitulorum and Fasciola gigantica causing Toxocariasis and Fascioliasis respectively, are considered the most important diseases impacting cattle and buffalo production in Laos [12,22,24-26].

FMD is widely acknowledged as a major limitation for efficient and sustainable livestock production [4,27]. In the GMS, FMD serotype $O$ is of most importance, causing a highly contagious endemic infection affecting mainly cattle and buffalo and compromising the livelihoods of smallholder farmers [28]. FMD outbreaks have been recorded for many years throughout Laos [25,29-30]. A recent study on the estimated financial impact due to FMD in Laos indicated the losses of FMD per household could exceed USD1,200, even when considering only the costs of treatment and losses due to mortality and morbidity [24]. Had other indirect costs attributable to a FMD outbreak been included, such as the cost of additional feed and labour needed to recover the weight lost during and post-infection, future production losses due to changes in herd structure including infertility, plus the opportunity costs of lost trade, it is very likely that the FMD-attributable financial losses of large ruminant smallholders would be much higher $[25,27]$.

HS is an acute fatal infectious and endemic disease of cattle and buffalo caused by the bacterium Pasteurella multocida type B2. It is widespread in Laos and particularly in remote areas where animals are kept under a free grazing system and vaccination is limited [31-32] with prevalence in buffalo usually between $2 \%$ and $12 \%$. However, the case fatality rate from HS is generally very high at between $43 \%$ and $73 \%$ [31]. Outbreaks of HS occurred in 2009 in Laos in many provinces causing the deaths of over 300 cattle and buffalo in one province alone (SK, personnel observations). That was followed by a series of outbreaks in 2009 and 2011 reported by farmers, although no available official records of reports on the disease outbreaks and financial impacts in Laos are available. A study in Cambodia estimated the financial losses due to HS per household and affected animal of USD952 and USD375, respectively [33]. The variation in the financial losses varied and depended on whether the animal survived, was provided with treatment, draught replacement was obtained and if there was a loss in secondary income.

Among the internal parasites of buffalo, $T$. vitulorum and $F$. gigantica are the most important parasites in Laos, as in many humid tropical regions in the world [34-37]. T. vitulorum is a pathogenic gastrointestinal nematode of newborn cattle and buffalo calves that is responsible for high morbidity and mortality rates of 15 50 days old calves [35-36]. Prevalence can reach $100 \%$ if no treatment and control is instituted, with deaths frequently occurring when associated with poor nutrition [35-36]. Clinical signs of infected calves include diarrhea, anorexia, loss of coat glossiness and skin tone with eczema, plus stunted growth. The life cycle of $T$. vitulorum has been well described [36] and a recent study in northern Laos revealed a prevalence of $23 \%$ with the parasite more common in buffalo than cattle calves [35]. Limited farmer knowledge on the parasite was also identified $[7,35]$.

F. gigantica is a trematode flat worm that can cause substantial negative impacts on large ruminant production [34,37]. Field and slaughterhouse studies in central and northern Laos revealed prevalence rates of $21-38 \%$ for $F$. gigantica in buffalo [23,34]. The widespread presence of these parasites in buffalo in Laos reflects the traditional large ruminant production systems that enhance the risk of significant parasitic disease losses, particularly through confounding factors including poor housing, nutritional deficiencies, unrestricted animal movements, shared water supplies, and lack of biosecurity controls $[4,9,23]$.

\section{SMALLHOLDER BUFFALO PRODUCTION IN LAOS}

Between 2005 and 2009, both the total and bovine meat production per capita increased steadily in Laos and neighbouring countries, with the exception of Thailand (Table 2) [38]. Meat production per capita per year in Laos increased from $17 \mathrm{~kg}$ to $21 \mathrm{~kg}$ between 2005 and 2009 [3] with $3.4 \mathrm{~kg}$ of that meat derived from buffalo. The Lao National Strategy for Agricultural Development from 2011 to 2020 is aimed at sustainable development of food and income security, emphasising the need for an increase in total meat supply to $40-50 \mathrm{~kg}$ per capita per year at $5 \%$ growth per annum [39]. Achieving this goal is a major challenge and it is considered that a systems approach with multiple interventions will be required. Improvements in animal health and production practices plus development of markets including improved supply linkages and information that supports 
Table 2: Meat Production in Laos and Neighbouring Countries, 2005-2009 (kg per capita per year)

\begin{tabular}{|c|c|c|c|c|c|c|c|}
\hline \multicolumn{2}{|c|}{ Countries/ Total and bovine meat } & \multicolumn{5}{|c|}{ Year } & \multirow{2}{*}{$\begin{array}{c}\% \text { Change pe } \\
\text { annum }\end{array}$} \\
\hline & & 2005 & 2006 & 2007 & 2008 & 2009 & \\
\hline \multirow{2}{*}{ Cambodia } & Bovine meat & 5.0 & 5.2 & 5.2 & 5.3 & 5.4 & 1.6 \\
\hline & Total & 16.1 & 16.1 & 16.2 & 16.2 & 16.6 & 0.6 \\
\hline \multirow{2}{*}{ China } & Bovine meat & 4.3 & 4.4 & 4.6 & 4.6 & 4.8 & 2.3 \\
\hline & Total & 53.4 & 54.4 & 52.9 & 56.3 & 58.2 & 1.8 \\
\hline \multirow{2}{*}{ Laos } & Bovine meat & 7.1 & 7.1 & 7.1 & 7.5 & 7.4 & 0.8 \\
\hline & Total & 17.4 & 18.1 & 18.5 & 20.2 & 21.3 & 4.5 \\
\hline \multirow{2}{*}{ Myanmar } & Bovine meat & 2.8 & 3.2 & 3.4 & 3.6 & 3.7 & 6.4 \\
\hline & Total & 23.6 & 26.8 & 29.6 & 32.4 & 32.1 & 7.2 \\
\hline \multirow{2}{*}{ Thailand } & Bovine meat & 2.3 & 2.5 & 2.7 & 2.9 & 2.9 & 5.2 \\
\hline & Total & 27.4 & 28.4 & 29.9 & 27.2 & 25.8 & -1.2 \\
\hline \multirow{2}{*}{ Vietnam } & Bovine meat & 3.0 & 3.1 & 3.7 & 3.9 & 4.3 & 8.7 \\
\hline & Total & 35.5 & 38.6 & 42.5 & 45.6 & 49.9 & 8.1 \\
\hline
\end{tabular}

Source: FAO, (2013), FAOSTAT (http://faostat.fao.org, accessed 15 July 2013).

smallholder livestock farmers to improve their productivity are necessary $[4,9,40]$.

There have been few documented studies on smallholder buffalo production under the free-grazing system in Laos until recently, when 500 local buffalo were enrolled in a longitudinal study and production data included body weight, average daily gains (ADG), calving rate and calving interval were measured between 2008 and 2011 [9,41]. This study established baseline production parameters of northern Lao smallholder buffalo, providing evidence of low mean weight (325-357 kg) and ADG (86-96 g/d). It confirmed that high variations occurred in body weights and ADG between seasons, reflecting the dramatic seasonal availability of feed resources, with animals in a negative energy balance during the dry period season from December to May [9,12,41].

Although disease control is crucial, improvement in Lao buffalo productivity cannot be achieved without provision of a more balanced nutrient supply, requiring improved management strategies [12,41]. The introduction of forage plantations has been promoted to assist smallholder farmers manage feed shortages in the dry season, plus provide a resource to commence fattening of buffalo prior to sale to increase animal values [10]. A recent on-farm fattening trial demonstrated a significant difference in ADG between the fattened and free-grazed buffalo, with fattened animals having an ADG of approximately $216 \mathrm{~g} / \mathrm{d}$, three-times greater than those free-grazed [9]. Further investigation on methods of improved nutritional and feeding management including silage preservation of forage for buffalo calves pre- and post- weaning is recommended.

Despite the unique ability of buffalo to better convert poor quality high fibre feed into milk and meat compared to cattle and sheep [19,42], the common practice of feeding untreated rice straw to buffalo should be limited. This is due to the lignifications and low nitrogen content of straw, resulting in an inability of buffalo to gain sufficient energy from such roughage [42]. Rice straw contains between 4 and $6.5 \mathrm{MJ}$ of ME per $\mathrm{kg}$ of dry matter and very low crude protein concentration of between $2 \%$ and $6 \%$ [43]. Improved 
utilization of crop residues in buffalo feeds via silagemaking using bags or concrete pits, plus the use of supplementation of roughage with urea and molasses, have been promoted [41-42]. Of interest is that in a study in the Philippines with crossbred buffalo fed a mixture of corn silage and concentrated feed, the ADG increased from $591 \mathrm{~g} / \mathrm{d}$ to $1,066 \mathrm{~g} / \mathrm{d}$ [44]. Improving both the quality and quantity of feed offered to cattle and buffalo is likely to achieve superior ADG for stall fattened animals in Laos and requires further investigation.

Improved husbandry practices and nutritional management are increasingly important for smallholder farmers to manage climate variability and potentially worsening environmental degradation. Although buffalo are well adapted to the tropics they have less physiological adaptation to extremes of heat than various breeds of Bos indicus cattle if unable to access water soaks [45-46]. Buffalo absorb a great deal of solar radiation because of the dominance of dark skin and sparse hair cover [46]. Heat stress occurs when total body heat exceeds heat loss and thermoregulation fails, resulting in excessive heat load and an increase in core temperature [47]. Increased climate variability with higher temperatures may well lead to heat stress becoming a more serious consideration for buffalo production. In contrast buffalo are also very susceptible to cold stress, as evidenced by a devastating incident of hypothermia in March 2011 that affected many villages in northern Laos, resulting in estimated losses of USD2.5 million due to the deaths of over 10,000 large ruminants including at least 3,744 buffalo [10]. Of interest, it has been estimated that the impact of climate change due to associated risks with unpredictable floods and drought could lead to $1.1 \%$ reduction to the Lao GDP particular from impacts on the agricultural sector $[39,48]$.

\section{MEAT CONSUMPTION, MARKETING AND TRADE OPPORTUNITIES FOR SMALLHOLDER BUFFALO FARMERS}

Increasing demand for animal products has been described as the livestock revolution, particularly in Asia [49] where economic growth has continued at a remarkable pace and is geographically widespread [1]. Higher incomes amongst urban consumers have led to diversification of their diet with the inclusion of more meat products [49]. Between 1997 and 2009, total meat consumption per capita per year in China increased from $43 \mathrm{~kg}$ to $58 \mathrm{~kg}$ and in Southeast Asia from $18 \mathrm{~kg}$ to $26 \mathrm{~kg}[3,11]$ with projections to grow at around $3.1 \%$ and $3.0 \%$ per annum to reach $73 \mathrm{~kg}$ and $30 \mathrm{~kg}$ by 2020 , respectively $[11,49]$. In Laos, total meat consumption was approximately $21 \mathrm{~kg}$ per capita per year in 2009, with an annual growth rate forecast of $4.5 \%$ [3]. Increasing demand for meat in both domestic and neighboring markets and China and Vietnam in particular, has been enhanced by the development of a regional road network throughout the GMS [6].

The estimated farm gate value of buffalo in Laos based on the total national herd has been suggested at USD531.9 million [50]. Approximately 100,000 live cattle and buffalo have been exported annually to neighbouring countries and particularly China and Vietnam, with the Lao government aiming to boost large ruminant exports to 140,000 by 2015 [39]. Of interest is that Vietnam is now seeking to import buffalo from Australia, with up to 5,000 per month reported to be arriving from February 2014 [51]. This indicates the high demand for buffalo in the region and the potential this species has as an export product from Laos to neighboring countries.

The increase in demand for beef in both domestic and in neighboring country markets appears to be exceeding current production levels. This has led to a surge in the prices of beef with media reporting the price of buffalo meat in Vientiane Capital increasing by almost $67 \%$ between April 2010 and April 2013, from approximately USD5.7 to USD9.4 per $\mathrm{kg}$ [52]. This demand is partly due to consumers in some northern Lao and southern Chinese provinces preferring buffalo meat over beef from cattle [7] as buffalo meat has a reputedly higher proportion of muscle to carcass and protein to fat content than meat from cattle [53]. As is the case in much of the GMS, considerable unregulated transboundary animal movements occur across porous international borders [54] with those traders operating in Laos and supplying these markets impacting on the local market for buffalo meat and potentially the sustainability of supply. The increasing prices for red meat and higher sale values of large ruminants are likely to have stimulated many smallholder farmers to sell more of their stock than in the past, although they are likely to struggle to replace their stock and maintain their livestock holdings. However it is also possible that the increasing prices for red meat could encourage large ruminant smallholders to improve their husbandry practices and seek improvements in reproductive management in an attempt to produce increased buffalo numbers to supply the increasing market demand. If numerous smallholders are successful in engaging this 
developing market for quality buffalo, sustained higher prices for the increasing supplies of better quality animals could contribute to rural poverty reduction in Laos and help address food insecurity in the GMS.

Despite increasing demand and trading opportunities, many Lao buffalo smallholder farmers have yet to take advantage of these changing circumstances due to the previously discussed production constraints plus limited marketing information. Currently, estimations of meat weight of buffalo and cattle is performed visually, a process subject to human error and bias by traders $[7,55]$. Smallholder buffalo farmers generally sell their livestock when they need large sums of money or the animals are ill and traders are usually able to set a low price, knowing that farmers are anxious to sell in order to obtain money and cut their losses [56]. Smallholder farmers may also be prevented from seeking reliable information on marketing conditions because of their geographic, social and economic isolation [57]. The existing imbalance of bargaining power between livestock traders and farmers can reduce the incentives for smallholders to improve product quality [7]. To facilitate improvements in large ruminant trade and productivity assessment, a weight tape enabling simple measurement of local buffalo and cattle has been developed [58]. Promotion of the regular use of this weight tape as a tool to more accurately estimate animal values is recommended. In addition, further research is recommended on livestock market chains, quality assurance and production data (e.g. mature weight and carcass percentage for local cattle and buffalo), as this information could support substantial improvements in livestock productivity for smallholder farmers.

\section{INTERVENTIONS TO IMPROVE SMALLHOLDER BUFFALO HEALTH AND PRODUCTION}

Significant attention in large ruminant livestock development projects is often given to 'breed improvement', involving the introduction of new genetics and development of hybrids and composites (particularly in the case of cattle), with the aim that farmers raise larger and more productive animals. However this strategy should be introduced to smallholder farmers with caution. In the absence of substantial improvements in basic animal health and husbandry capacities of smallholders including nutritional and reproductive management, the introduction of animals requiring higher ME inputs for their maintenance needs and controlled breeding, has a high risk of failure under the current management practices.

Vaccination rates for important infectious diseases of large ruminants and particularly for HS are low in Laos due to inadequate veterinary services [14]. However, the regular occurrence of endemic diseases in buffalo is not only an indication of low vaccination coverage but more significantly, reflects the widespread poor biosecurity practices that reflect the low levels of farmer knowledge of infectious disease. Biosecurity includes all the hygienic practices designed to reduce the risk of infectious agents entering a herd, spreading within a herd, or entering and spreading within and beyond a country [59]. The introduction of vaccination programs accompanied by farmer knowledge training through farm cross-visits, applied research and on the job training is considered the highest priority, followed by nutritional management, parasite control and reproductive management $[4,41]$. Importantly, the introduction of village-level biosecurity practices should be conducted at an appropriate pace using a participatory approach to ensure the acceptance and sustainability of the programs [7]. Depending on vaccine availability, vaccinations for FMD and HS should be implemented twice per year in May-June and November-December as these were identified as high risk periods for the disease infection [30-31]. Although treatment for $T$. vitulorum infestation is not expensive or inconvenient [35-36] many smallholder farmers tend to forget this practice, hence repetition of extension messages focused in the calving season between November and March is recommended [9].

\section{CONCLUSION}

To facilitate the transition of smallholder buffalo keepers to more market-oriented producers, livestock development policies in Laos should promote the adoption of a multiple intervention approach toward animal health and disease risk management, improved farmer biosecurity knowledge and practices, improved feeding and reproductive practices as well as measures to improve market linkages, all of which will help smallholder buffalo farmers to improve their productivity and gain market access $[4,7]$. This learning process takes considerable time and requires ongoing support and close collaboration with research and development programs to improve extension capacity, animal movement control, disease surveillance, public awareness, vaccination programs, feed resources and reproductive management [4]. Importantly, 
harmonization of government and aid donor support and extension policies from national, provincial and district level is crucial for the development of the buffalo meat industry. For instance, the expansion of cash crop plantations and land concessions [39] should be carefully implemented to avoid creating pressure on land availability for buffalo grazing and expansion of the buffalo population. Without addressing critical constraints in health, productivity and trade, the growing demand may further outstrip supply, compromising efforts that seek to improve food security and poverty reduction. Improvements in buffalo productivity in Laos will offer opportunities for smallholders to develop small to medium-sized buffalo producing enterprises, assisting the alleviation of rural poverty and reducing food insecurity in Laos and the GMS.

\section{ACKNOWLEDGEMENT}

This paper reviewed studies conducted with financial support from the Australian Centre for International Agricultural Research (ACIAR AH 2006/159), with scholarship support (for SN) from the ACIAR John Allwright Fellowship. The assistance of Dr L. Rast, Ms N Matsumoto and staff of the Lao Department of Livestock and Fisheries is gratefully acknowledged.

\section{REFERNCES}

[1] World Bank. World development indicator Washington, DC: World Bank 2013.

[2] Ministry of Agriculture and Forestry. Strategy for agricultural development 2011 to 2020, Vientiane, Laos 2010.

[3] FAO. Selected indicators of food and agricultural development in the Asia-Pacific Region 2001-2011. Food and Agriculture Organization of the United Nations (FAO), Regional office for Asia and the Pacific (RAP) Publication 2012/18, Bangkok, Thailand 2012

[4] Windsor PA. Perspectives on Australian Animal Health Aid Project in South-East Asia. Transbound Emerg Dis 2011; 58: 375-86.

http://dx.doi.org/10.1111/j.1865-1682.2011.01216.x

[5] United Nations Children Fund (UNICEF). The state of the world's children. United Nation, New York, USA 2012.

[6] Asian Development Bank (ADB). Participatory Livestock Development Project ADB PPTT No. 4287- Lao. Vientiane, Lao PDR 2005

[7] Nampanya S, Rast L, Khounsy S, Windsor PA. Assessment of Farmer Knowledge of Large Ruminant Health and Production in Developing Village-Level Biosecurity in Northern Lao PDR. Transbound Emerg Dis 2010; 57: 42029.

http://dx.doi.org/10.1111/j.1865-1682.2010.01168.x

[8] Wilson R. Status and prospects for livestock production in the Lao People's Democratic Republic. Tropical Animal Health and Production 2007; 39: 443-52.

http://dx.doi.org/10.1007/s11250-007-9048-7
[9] Nampanya S, Khounsy S, Rast L, Young JR, Bush RD, Windsor PA. Progress in smallholder large ruminant productivity to reduce rural poverty and address food security in upland northern Lao PDR. An Prod Sc 2013; AN13180.

[10] Khounsy $S$, Nampanya $S$, Inthavong $P$, Yang $M$, Khamboungheung B, Avery M, Bush R, Rast L, Windsor PA. Significant mortality of large ruminants due to hypothermia in northern and central Lao PDR. Tropical Animal Health and Production 2012; 44(4): 835-42. http://dx.doi.org/10.1007/s11250-011-9975-1

[11] Delgado C. Rising consumption of meat and milk in developing countries has created a new food revolution. $J$ Nutr 2003; 3907-3910S.

[12] Stür W, Gray G, Bastin G. Review of the livestock sector in the Lao people's Democratic Republic. International Livestock Research Institute: Manila, Philippines 2002.

[13] McDermott JJ, Staal SJ, Freeman HA, Herrero M, Van de Steeg JA. Sustaining intensification of smallholder livestock systems in the tropics. Livestock Sci 2010; 130: 95-109. http://dx.doi.org/10.1016/j.livsci.2010.02.014

[14] Steering Committee for Lao Census of Agriculture. Lao Census of Agriculture 2010/11. Department of Planning, Ministry of Agriculture and Forestry, Vientiane, Lao PDR 2012.

[15] Ministry of Planning and Investment, 2011, The Seventh Five-year National Socio Economic Development Plan (2011-2015), Vientiane, Laos; 2011

[16] Barile VL. Reproductive efficiency in female buffaloes. In Borghese A, editor. Buffalo production and research. REU Technical Series (67) Rome: FAO 2005; pp. 77-107.

[17] Patro BN, Mishra PK, Rao PK. Chilika buffaloes in Orissa: a unique germplasm (Animal Genetic Resources Information). FAO 2003; 33: 73-79.

[18] Perera BMAO. Reproductive cycles of buffalo. Anim Reprod Sci 2011; 124: 194-99. http://dx.doi.org/10.1016/j.anireprosci.2010.08.022

[19] Sarwar M, Khan MA, Nisa M, Bhatti SA, Shahzad MA Nutritional Management for Buffalo Production, Asian-Aust. $J$ Anim Sci 2009; 22(7): 1060-68

[20] Dixon RM, Playford C, Coates DB. Nutrition of beef breeder cows in the dry tropics. 2. Effects of time of weaning and diet quality on breeder performance. Anim Product Sci 2011; 51: 529-40. http://dx.doi.org/10.1071/AN10083

[21] Rasby R. Early Weaning Beef Calves. Veter Clin Food Anim Pract 2007; 23: 29-40. http://dx.doi.org/10.1016/j.cvfa.2007.01.002

[22] Ministry of Agriculture and Forestry. Law on livestock production and veterinary matters (translation), Vientiane. Laos 2008

[23] Rast L. Toxocara vitulorum \& Fasciola gigantica in Cattle and Buffalo in Northern Laos, PhD thesis,Faculty of Verterinary Science, University of Sydney, Australia 2014.

[24] Nampanya S, Khounsy S, Phonvisay A, Young JR, Bush RD, Windsor PA. Financial impact of Foot and Mouth Disease on large ruminant smallholder farmers in the Upper Mekong region. Transb Emerg Dis 2013. http://dx.doi.org/10.1111/tbed.12183

[25] Rast L, Windsor PA, Khounsy S. Limiting the impacts of foot and mouth disease in large ruminants in northern Lao People's Democratic Republic by vaccination: A case study. Transbound Emerg Dis 2010; 57: 147-53. http://dx.doi.org/10.1111/j.1865-1682.2010.01099.x

[26] Windsor $\mathrm{P}$, Suon S, Khounsy S. Identifying research priorities for development for the beef industry in Cambodia and Lao PDR with special reference to animal health intervention $\mathrm{AH} / 2006 / 077$. Australian Centre for International Agricultural 
Research (ACIA), Canberra, Australia 2008; [cited 2010 August 20]. Available from: http://www.aciar.gov.au/project/ $\mathrm{AH} / 2006 / 077$

[27] Rushton J. The Economics of Animal Health and Production, CAB International: Oxfordshire, UK 2009

[28] OIE Sub-Regional Representation for South-East Asia. South East Asia and China Foot and Mouth Disease campaign (SEACFMD) 2020 a roadmap to prevent, control and eradicate foot and mouth disease freedom (by2020) in South-East Asia and China, $2^{\text {nd }}$ ed, Bangkok, Thailand 2011.

[29] Khounsy S, Colan J, Gleeson L, Westbury H, Colling A, Paton D, Ferris N, Valarcher J, Wadsworth J, Knowles N, Blacksell S. Short communication: molecular epidemiology of foot-and-mouth disease viruses from South-East Asia 19982006 the Lao perspective. Vet Microbiol 2009; 135: 429799.

[30] Nampanya S, Richards J, Khounsy S, Inthavong P, Yang M, Rast L, Windsor PA. Investigation of Foot and Mouth Disease hotspots in northern Lao PDR. Transbound Emerg Dis 2013; 60: 315-29. http://dx.doi.org/10.1111/j.1865-1682.2012.01350.x

[31] De Alwis MCL. Haemorrhagic Septicaemia. Australian Centre for International Agricultural Research (ACIAR) Monograph 57. Canberra, Australia 1999.

[32] Benkirane A, De Alwis MCL. Haemorrhagic septicaemia, its significance, prevention and control in Asia. Vet Med 2002; 47: $234-40$

[33] Kawasaki M, Young JR, Suon S, Bush RD, Windsor PA. The socioeconomic impacts of Haemorrhagic Septicaemia on smallholder large ruminant farmers in Cambodia. Transb Emerg Dis 2013 http://dx.doi.org/10.1111/tbed.12174

[34] Copeman D, Copland R. Importance and potential impact of liver fluke in cattle and buffalo. In: Gray G, Copland R, Copeman D, Eds., overcoming liver fluke as a constraint to ruminant production in South-East Asia, Australian Centre for International Agricultural Research (ACIAR) Monograph no.133. Canberra, Australia 2008; pp. 21- 25.

[35] Rast L, Lee S, Nampanya S, Toribio J, Khounsy S, Windsor PA. Prevalence and clinical impact of Toxocara vitulorum in cattle and buffalo calves in northern Lao PDR. Trop Anim Health Product 2013; 45(2): 539-46. http://dx.doi.org/10.1007/s11250-012-0256-4

[36] Starke-Buzetti WA. Toxocara vitulorum in livestock, In: Holland CV, Smith HV, Eds. Toxocara: the enigmatic parasite, CAB International: Wallingford, UK 2006; pp. 260266

[37] Tum S, Puotinen M, Skerratt L, Chan B, Sothoeun S. Short communication: Validation of geographic information system model for mapping the risk of fascioliasis in cattle and buffalo in Cambodia. Veter Parasitol 2007; 143: 364-67. http://dx.doi.org/10.1016/j.vetpar.2006.08.033

[38] FAO. FAOSTAT online database. Food and Agriculture Organisation of the United Nations (FAO), Rome, Italy. 2013; [cited 2013 July 15] Available from: http://faostat.fao.org/site

[39] Ministry of Planning and Investment, 2011, The Seventh Five-year National Socio- Economic Development Plan (2011-2015), Vientiane, Laos 2011.

[40] Arias P, Hallam D, Krivonos E, Morrison J. Smallholder integration in changing food markets, Food and Agriculture Organization of the United Nations, Rome 2013.

[41] Nampanya S, Khounsy S, Rast L,Windsor PA. Promoting transboundary animal disease risk management through multiple large ruminant health and husbandry interventions in upland Lao PDR. Trop Anim Health Product 2013; 46(2): 439-46.

http://dx.doi.org/10.1007/s11250-013-0511-3
[42] Agarwal N, Kamra DN, Chatterjee PN, Kumar R, Chaudhary LC. In vitro methanogenesis, microbial profile and fermentation of green forages with buffalo rumen liquor as influenced by 2-Bromoethanesulphonic acid. Asian- Aust J Anim Sci 2008; 21: 818-23.

[43] Nour AM. Rice Straw and Rice Hulls in Feeding Ruminants in Egypt. Department of Animal Production, Faculty Of Agriculture, Alexandria University, Alexandria, Egypt 2003.

[44] Lapitan RM, Del Barrio AN, Katsube O, Tokuda T, Orden EA Robles AY, Fujihara T, Cruz LC, Kanai Y. Comparison of feed intake, digestibility and fattening performance of Brahman grade cattle (Bos indicus) and crossbred water buffalo (Bubalus bubalis). Anim Sci J 2004; 75: 549-55. http://dx.doi.org/10.1111/j.1740-0929.2004.00226.x

[45] Ahmad S, Tariq M. Heat Stress Management in water buffaloes: A review. In Proceeds of the $9^{\text {th }}$ World Buffalo Congress, Argentina 2010; 297-310.

[46] Maria IFM, Haeeb AAM. Buffalo's biological functions as affected by heat stress-A review. Livestock Sci 2010; 127 89-109. http://dx.doi.org/10.1016/j.livsci.2009.08.001

[47] Gaughan J, Mader TL, Holt S, Lisle A. A new heat load index for feedlot cattle. J Anim Sci 2008; 86: 226-34. http://dx.doi.org/10.2527/jas.2007-0305

[48] Asian Development Bank (ADB), World Bank Country Gender Assessment for Lao PDR-Reducing Vulnerability and Increasing Opportunity. Mandaluyong City, Philippines and Washington, D.C., USA 2012.

[49] Delgado C, Rosegrant M, Steinfield H, Ehui S, Courbois C. Livestock to 2020: The food revolution, food, agriculture and the environment. Discussion Paper 28. International Food Policy Research Institute, Washington DC, USA 1999.

[50] Young JR, Nampanya S, Khounsy S, Bush RD, Windsor PA. Improving trade in large ruminants and products by transboundary animal disease control in Lao PDR. J Veter Sci 2014; (accepted in March 7, 2014)

[51] Australian Broadcasting Corporation (ABC) Rural. First live buffalo shipment headed for Vietnam. 2014 [cited 2014 February 14]. Available from: http://www.abc.net.au/news/ 2014-01-30/first-territory-buffalo-shipment-headed-forvietnam/5227736.

[52] Lao News Agency (KPL). Goods prices during the Pimay celebration rise, Vientiane, Lao PDR. 2013 [cited 2013 July 25]. Available from: http://www.kpl.net.la/english/news/ newsrecord /2013/April/18.4.2013/edn4.htm

[53] Rey JF, Povea IE. Water buffalo (Bubalus bubalis) and their technological advantages for the design in healthy meat product. J Buffalo Sci 2012; 1: 183-87.

[54] Kerr J, Sieng S, Scoizec A, Working with traders to understand livestock movements and spread of animal diseases in Cambodia and Lao PDR, In: Adams LB, Gray GD, Murray G, editors, Animal Biosecurity in the Mekong: Future Directions for Research and Development, SiemReap, Cambodia, Australian Centre for International Agricultural Research (ACIAR) Proceedings 137. Canberra, Australia 2012; pp. 59-60.

[55] Machila N, Fevre EM, Maudlin I, Eisler MC. Farmer estimation of live bodyweight of cattle: Implications for veterinary drug dosing in East Africa. Prevent Veter Med 2008; 87: 394-403. http://dx.doi.org/10.1016/j.prevetmed.2008.06.001

[56] Rweyemamu M, Roeder P, Mackay D, Sumption K, Brownlie J, Leforban Y, Valarcher J, Knowles N, Saraiva V. Review epidemiology patterns of foot-and mouth disease worldwide. Transbound Emerg Dis 2008; 55: 57-72. http://dx.doi.org/10.1111/j.1865-1682.2007.01013.x 
[57] Chadwick K, Otte J, Roland-Holst D. Information Failure in Livestock Market: Evidence from Lao PDR. FAOPPLPI Research Report. Rome, Italy 2008.

[58] Bush RD, Page B, MacDonald T, Young J, Nampanya S, Suon S, Khounsy S, Henry L, Thomson PC, Windsor PA. Target feeding for improved smallholder beef production in the Mekong region: lessons from Cambodia and Lao PDR. Anim Product Sci 2014; (Submitted in March 2014)

[59] Larson R. Epidemiology and disease control in everyday beef practice. Theriogenology 2008; 70: 565-68.

http://dx.doi.org/10.1016/j.theriogenology.2008.04.011

(C) 2014 Nampanya et al.; Licensee Lifescience Global.

This is an open access article licensed under the terms of the Creative Commons Attribution Non-Commercial License (http://creativecommons.org/licenses/by-nc/3.0/) which permits unrestricted, non-commercial use, distribution and reproduction in any medium, provided the work is properly cited. 